\title{
Stock returns-inflation nexus in Indonesia: Evidence from conventional and Islamic stocks
}

\author{
Yahya, M. Shabri Abd. Majid, Hafasnuddin
}

\begin{abstract}
A B S T R A C T
Objective: The objective of the article is to empirically explore the effects of actual, expected, and unexpected inflation on conventional and Islamic stock markets in Indonesia.

Research Design \& Methods: In the first stage, an auto-regressive integrated moving average (ARIMA) model is utilized to measure expected and unexpected inflations. In the second stage, a dynamic ordinary least squares (DOLS) estimator is used to explore the stock return-inflation nexus over the period from 1999 to 2019.

Findings: The study documented that Islamic stock returns are independent of inflation following the Fisher hypothesis. Meanwhile, a negative relationship between stock returns and inflation is found in the conventional stock market. However, the Fama proxy hypothesis was incapable of describing the negative conventional stock returns-inflation relation in its entirety. However, our findings support the Mundell-Tobin hypothesis.

Implications \& Recommendations: Our findings imply that the Islamic stock market of Indonesia provides a full hedge against actual, while the conventional stock market does not.

Contribution \& Value Added: This study is the first attempt in the Islamic finance literature to comparatively explore the effects of inflation, expected, and unexpected inflation on conventional and Islamic stock markets from the perspective of the emerging Indonesian economy.
Article type: research article
Keywords: $\quad$ Fisher hypothesis; Fama proxy hypothesis; Islamic stock; hedge

JEL codes: $\quad$ C22, C58, G11

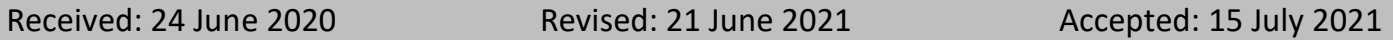

\section{Suggested citation:}

Yahya, Majid, M.S.A., \& Hafasnuddin. (2021). Stock returns-inflation nexus in Indonesia: Evidence from conventional and Islamic stocks. Entrepreneurial Business and Economics Review, 9(4), 131-146. https://doi.org/10.15678/EBER.2021.090409

\section{INTRODUCTION}

The stock return-inflation relation has been a puzzle in financial economics theory. Some studies found a positive (Durai \& Bhaduri, 2009; Li et al., 2010; Alagidede \& Panagiotidis, 2012; Tiwari et al., 2015; Zhao, 2017) and negative (Gallagher \& Taylor, 2002; Kim, 2003; Li et al., 2010; Aktürk, 2016; Antonakakis et al., 2017) association between stock return and inflation, while few others discovered the independence (Majid, 2006; Haniff \& Masih, 2018) of stocks from inflation. The nature of the stock return-inflation nexus provides necessary implications for the investors as to whether stocks are a better hedge against inflation or not. A positive or an independent stock return-inflation association implies a better hedge of stock returns against inflation.

Previous studies have proposed various hypotheses to describe the nature of the stock return-inflation relation. The Fisher (1930) hypothesis explains that real stock return is independent of inflationary predictions, while a negative relationship between unemployment and inflation rates - as stated by the Phillips curve (1958) - stock returns are positively associated with inflation. On the other hand, many other hypotheses propose an inverse stock return-inflation relation. These include Mundell's (1963) views, Tobin's (1965) hypothesis, Modigliani and Cohn's (1979) inflation illusion hypothesis, Feldstein's 
(1982) tax hypothesis, Fama's $(1981,1883)$ proxy hypothesis, Bulmash's $(1991)$ quantity of money hypothesis, and Brandt and Wang's (2003) time-varying risk aversion hypothesis. Additionally, to reconcile a negative and a positive correlation in the post-war period, Kaul $(1987,1990)$ and Hess and Lee (1999) introduce the equilibrium mechanism in the monetary sector to real economic activity. They adopt the two-regime hypothesis and a structural bivariate vector autoregression model, respectively.

Previous studies mainly focus on the actual inflation-stock returns puzzle in the conventional stock markets in developed and emerging economies. These studies explore the inflation-stock returns puzzle in 11 advanced economies (Lee, 2010), the G7 countries (Alagidede \& Panagiotidis, 2012), the USA (Gallagher \& Taylor, 2002; Antonakakis et al., 2017), the UK (Li et al., 2010), Germany (Kim, 2003), Greece (Floros, 2004), Turkey (Aktürk, 2016), China (Zhao, 2017), India (Durai \& Bhaduri, 2009; Jana, 2013), Pakistan (Tawari et al., 2015), Malaysia (Majid, 2002; Haniff \& Masih, 2018), and Indonesia (Majid, 2006). Meanwhile, Qizam (2020) found a positive and an insignificant effect of Islamic bond (sukuk) ratings on Malaysian and Indonesian stock returns, respectively.

Even though the previous literature on the stock return-inflation puzzle is voluminous and rich, only Haniff and Masih (2018) investigate the stock return-inflation puzzle for the case of the Islamic stock market in Malaysia over the period 2007-2015 using the wavelet technique. However, none of the earlier studies has investigated the relationship between actual, expected, unexpected inflation and both conventional and Islamic stock returns.

Although the Islamic capital markets have been growing at a remarkable pace since their inception in the 1990s and research on Islamic finance flourished in recent years, the studies considering the actual, expected, and unexpected inflation and Islamic stocks relationships are non-existent. Thus, they fail to provide a far-reaching implication as to whether Islamic stocks offer a good hedge against inflation. Does inflation have a similar effect on both conventional and Islamic stock markets? Does the Islamic stock market provide a good hedge against inflation as its conventional counterparts? These are not trivial questions to be left unanswered due to the different nature and characteristics of Islamic stocks as compared to the conventional ones. Unlike the conventional market, the core business activity of a company listed in the Islamic stock market should comply with sharia principles that are free from the elements of interest (riba), uncertainty (gharar), and gambling (maysir).

Thus, to fill the above research gaps, this study explores the relationships between actual, expected, and unexpected inflation and both Indonesian conventional and Islamic stocks using a more extended study period from 1999-2019 (21 years) within the framework of the Fama proxy hypothesis $(1981,1983)$. Fama $(1981,1983)$ posits that a negative stock return-inflation relation is explained by a negative inflation-real economic activity and a positive real activity-stock returns nexus.

We hope that our findings will enrich the existing literature on the stock return-inflation puzzle from a new perspective of Islamic stocks. Moreover, the study findings will hopefully shed light on the investors and international fund managers who seek to diversify their investments in the Indonesian stock markets, both the conventional and the Islamic one.

The rest of this study is structured in the following manner. The next section reviews the selected literature on the stock return-inflation puzzle. Then, we provide an empirical framework as the basis for data analysis. The following section discusses the main findings and their implications, and finally, conclusion summarizes the study.

\section{LITERATURE REVIEW}

\section{Theories of stock return-inflation nexus}

The studies on the stock return-inflation nexus puzzle have recently been extensively explored using various approaches and financial economics theories. Previous studies that investigated the stock return-inflation association in the global capital markets have documented mixed findings. The stock return-inflation relation was found to be positive (Durai \& Bhaduri, 2009; Alagidede \& Panagiotidis, 2012; Aktürk, 2016; Zhao), negative (Kim, 2003; Lee, 2010; Li et al., 2010; Antonakakis et al., 2017), and independent (Gallagher \& Taylor, 2002; Tiwari et al., 2015; Haniff \& Masih, 2018). Due to these mixed findings and, consequently, their implications, the stock return-inflation relation has been a 
puzzle in financial economics theory. The existence of positive or independent stock return-inflation relation implies a better hedge of stocks against inflation. In contrast, the presence of a negative association between them implies otherwise.

According to the Fisher (1930) hypothesis, real stock returns are independent of inflation, implying that nominal asset returns have to be positively associated with expected and unexpected inflation. A positive stock return-inflation relation could also be explained by Phillips (1958) curve, which shows that a negative unemployment-inflation relationship implies a direct inflation-real economic activity association. Accordingly, stock return positively related to real economic activity is in turn supposed to have a positive relation to inflation.

However, recent empirical findings contradict the Fisher hypothesis and the Phillips curve in which inflation-stock returns are negatively related (Fama, 1981, 1983; Chatrath et al., 1997; Majid, 2006; Lee, 2010; Li et al., 2010; Antonakakis et al., 2017). For example, Chatrath et al. (1997), Majid (2006), Gallagher and Taylor (2002), Kim (2003), and Durai and Bhaduri (2009) utilize Fama's proxy hypothesis $(1981,1983)$ to elucidate negative stock returns-inflation connection. According to Fama's proxy hypothesis $(1981,1983)$, the negative stock return-inflation relation could be clarified by a negative inflation-real economic activity and a positive real activity-stock return nexus.

Based on the above discussion, the study proposes the following first hypothesis:

H1: There is a negative association between stock returns and actual, expected, and unexpected inflation.

In his proxy hypothesis, Fama $(1981,1983)$ only hypothesizes the nature of the relationship between actual inflation and stock return. However, this study extends the analysis to include both expected and unexpected inflation and their relationships to stock returns to provide a comprehensive picture of the nature of various types of inflation-stock return nexus.

Moreover, some studies found that the Fama proxy hypothesis fails to explain the negative stock return-inflation relationship (Ram \& Spencer, 1983; Majid, 2002; Haniff \& Masih, 2018). Instead, as an alternative to Fama's proxy hypothesis, Mundell (1963) and Tobin (1965) explain that the rise in the predicted inflation rate drives portfolio substitutions from money to financial assets and diminishes the real stock returns. The decline in real interest stimulates economic activity. Thus, a positive inflation-economic activity and a negative real stock return-economic activity nexus should be expected (Ram \& Spencer, 1983).

Additionally, the negative stock return-inflation relation is explained by Modigliani and Cohn's (1979) inflation illusion hypothesis. This hypothesis states that investors in stocks tend to discount expected future dividends and earnings more profoundly by using higher nominal interest rates when inflation rises. Consequently, stock prices are undervalued when inflation increases and become overvalued when inflation declines, resulting in the negative stock return-inflation relation. Using the theory of rational valuation, Modigliani and Cohn (1982) explain that the low stock values throughout periods of high inflation result from the failure of investors to alter company profits for the inflation premium elements of interest expense - representing a capital return rather than an expense - and from the capitalization of company profits at the nominal rate, instead of the theoretical adjustment of the real rate of interest.

Feldstein (1982) suggests an inverse stock return-inflation relation in the US stock market by using the tax hypothesis. According to him, a significant indirect effect of increased inflation on stock price is caused by essential characteristics of the US tax law, predominantly the remarkable cost depreciation and taxation of nominal capital gains. Using a time-varying risk aversion hypothesis, Brandt and Wang (2003) contend that inflation causes investors to become more risk-averse, steering up the stock premium and the real discount rate, thus reducing real stock returns.

Furthermore, in their research on the stock markets of the USA, the UK, Japan, and Germany, Hess and Lee (1999) offer a two-regime hypothesis that drives the stock return-inflation nexus based on different shocks of aggregate demand and supply in the pre-war period (1926-1944) and the post-war period (1947-1994). They found that the aggregate demand shocks drive a positive relationship in the pre-war period, while the aggregate supply shocks drive a negative relationship in the post-war period. 
In the presence of real supply shocks, the estimation of the Phillips curve is to be biased, while during the period of an unanticipated monetary shock there is to exist a positive inflation-real stock returns association. On the other hand, a negative relationship between inflation-real stock returns is to emerge in the short-run due to the dominance of fluctuations in the natural rate of output over the cyclical component of a Lucas-type Phillips curve (Kryzanowski \& Rahman, 2009).

Finally, Haniff and Masih (2018) study the stock return-inflation puzzle for the Malaysian Islamic stock market over the 2007-2015 period using the Wavelet technique. They document that the Islamic stock provides a potential hedge against inflation during the normal economic period but not during the 2008-2009 period, following the global financial crisis.

The above-reviewed studies on stock return-inflation relation have proposed and tested various hypotheses, as summarised in Table 1.

Table 1. Summary of various hypotheses on stock return-inflation nexus

\begin{tabular}{|c|c|c|c|}
\hline No. & Hypothesis & Statement & Author \\
\hline 1. & Fisher (1930) hypothesis & Real stock returns are independent of inflation & Fisher (1930) \\
\hline 2. & Phillips curve & A positive inflation-stock relation. & Phillips (1958) \\
\hline 3. & Proxy hypothesis & $\begin{array}{l}\text { A negative stock returns-inflation relation. Explained } \\
\text { by a negative inflation-real economic activity and a } \\
\text { positive real activity-stock returns association. }\end{array}$ & Fama $(1981,1983)$ \\
\hline 4. & Mundell-Tobin hypothesis & $\begin{array}{l}\text { A negative stock returns-inflation relation. Explained } \\
\text { by a positive inflation-economic activity and a nega- } \\
\text { tive real stock return-economic activity relation. }\end{array}$ & $\begin{array}{l}\text { Mundell (1963) } \\
\text { Tobin (1965) }\end{array}$ \\
\hline 5. & Inflation illusion hypothesis & A negative stock return-inflation relation. & $\begin{array}{l}\text { Modigliani and } \\
\text { Cohn (1979) }\end{array}$ \\
\hline 6. & Theory of rational valuation & A negative stock return-inflation relation. & $\begin{array}{l}\text { Modigliani and } \\
\text { Cohn (1982) } \\
\end{array}$ \\
\hline 7. & Tax hypothesis & An inverse stock return-inflation relation. & Feldstein (1982) \\
\hline 8. & Two-regime hypothesis & $\begin{array}{l}\text { A positive stock return-inflation relation in the pre- } \\
\text { war period due to an aggregate demand shock. } \\
\text { A negative stock return-inflation relation in the post- } \\
\text { war period due to an aggregate supply shock. }\end{array}$ & Hess and Lee (1999) \\
\hline 9. & $\begin{array}{l}\text { Time-varying risk aversion } \\
\text { hypothesis }\end{array}$ & An inverse stock return-inflation relation. & $\begin{array}{l}\text { Brandt and Wang } \\
(2003)\end{array}$ \\
\hline 10. & $\begin{array}{l}\text { Generalized Fama proxy hy- } \\
\text { pothesis }\end{array}$ & $\begin{array}{l}\text { A positive inflation-real stock returns association in a } \\
\text { long run. } \\
\text { A negative inflation-real stock returns association in } \\
\text { the short-run. }\end{array}$ & $\begin{array}{l}\text { Kryzanowski and } \\
\text { Rahman (2009) }\end{array}$ \\
\hline
\end{tabular}

Source: own study.

Referring to the above discussion, the study tests a negative stock returns-and inflation relation using Fama's $(1981,1983)$ proposition in the following second and third hypotheses:

H2: There is a negative association between actual, expected, and unexpected inflation and real economic activity.

H3: There is a positive association between real economic activity and stock returns.

Our hypotheses extend the proxy hypothesis of Fama $(1981,1983)$ by incorporating not only actual inflation but also both expected and unexpected inflation-stock return nexus to provide an entire nature of relationships between various types of inflation and stock return.

\section{RESEARCH METHODOLOGY}

In the first step, this study empirically explored the stock returns-inflation puzzles for the case of Islamic and conventional stocks in the emerging Indonesian market using the Fisher hypothesis. 
Meanwhile, the nature of the stock returns-inflation relation was tested in the second step using the Fama proxy hypothesis.

\section{Testing the Fisher hypothesis}

This study explored the effects of actual, expected, and unexpected inflation on real stock returns. Therefore, three econometric models were formulated to test both conventional and Islamic stock returns' relationship to each type of inflation. Following the studies by Chatrath et al. (1997) and Majid (2006), the following first model was proposed to test the stock returns and actual inflation relation:

$$
\begin{aligned}
& c S R_{t}-I N F_{t}=\beta_{0}+\beta_{1}\left(I N F_{t}\right)+\varepsilon_{t} \\
& i S R_{t}-I N F_{t}=\beta_{0}+\beta_{1}\left(I N F_{t}\right)+\varepsilon_{t}
\end{aligned}
$$

in which $C S R$ was the nominal returns of conventional stock, iSR is the nominal returns of Islamic stock, and $I N F$ was the actual rate of inflation over period $t$. The difference, $S R_{t}-I N F_{t}$ represented real returns, and $\varepsilon_{t}$ was the error random term.

Similarly, to explore the stock returns-expected inflation relation, the following second model was proposed:

$$
\begin{aligned}
& c S R_{t}-I N F_{t}=\beta_{0}+\beta_{2} E\left(I N F_{t} I \phi_{t-i}\right)+\varepsilon_{t} \\
& i S R_{t}-I N F_{t}=\beta_{0}+\beta_{2} E\left(I N F_{t} I \phi_{t-i}\right)+\varepsilon_{t}
\end{aligned}
$$

in which $E\left(I N F_{t}\right)$ denoted the expected inflation rate at the time $t$ and $I \phi_{t-i}$ is the information set accessible to investors at the end of period $t-i$.

Finally, the third model was proposed to test the association between stock returns and both expected and unexpected inflation, as follows:

$$
\begin{aligned}
& c S R_{t}-I N F_{t}=\beta_{0}+\beta_{2} E\left(I N F_{t} I \phi_{t-i}\right)+\beta_{3} U E\left(I N F_{t}\right)+\varepsilon_{t} \\
& i S R_{t}-I N F_{t}=\beta_{0}+\beta_{2} E\left(I N F_{t} I \phi_{t-i}\right)+\beta_{3} U E\left(I N F_{t}\right)+\varepsilon_{t}
\end{aligned}
$$

in which the unexpected inflation rate, $U E\left(I N F_{t}\right)$ was described as the difference between actual and expected rates of inflation $\left[I N F_{t}-E\left(I N F_{t} I \phi_{t-i}\right)\right]$.

For the first two equations (3.1) and (3.2), if the estimated coefficients of $\beta_{1}$ and $\beta_{2}$ equalled zero, they would agree with the Fisher hypothesis, which states that real stock returns are independent of inflation rates, implying a perfect hedge of stocks against inflation and expected inflation, respectively. Meanwhile, the $\beta_{2}=\beta_{3}=0$ in equation (3.3) indicated a full hedge of stocks against both expected and unexpected inflation.

\section{Testing Fama's proxy hypothesis}

As mentioned earlier, Fama's proxy hypothesis explains that a negative stock returns and inflation relation centres on the inflation-real economic activity and stock returns-real economic activity linkages. Thus, the first proposition of Fama's proxy hypothesis (a negative inflation-real economic activity association) and the second proposition of Fama's proxy hypothesis (a positive real economic activitystock returns association) could then be separately measured by the following models:

$$
\begin{gathered}
I N F_{t}=\alpha_{0}+\sum_{i=-k}^{k} \alpha_{i} R E A_{t+i}+\varepsilon_{t} \\
E\left(I N F_{t}\right)=\alpha_{0}+\sum_{i=-k}^{k} \alpha_{i} R E A_{t+i}+\varepsilon_{t} \\
U E\left(I N F_{t}\right)=\alpha_{0}+\sum_{i=-k}^{k} \alpha_{i} R E A_{t+i}+\varepsilon_{t} \\
S R_{t}-\left(I N F_{t}\right)=\delta_{0}+\sum_{i=-k}^{k} \delta_{i} R E A_{t+i}+v_{t} \\
i S R_{t}-\left(I N F_{t}\right)=\delta_{0}+\sum_{i=-k}^{k} \delta_{i} R E A_{t+i}+v_{t}
\end{gathered}
$$

in which $R E A_{t}$ was the real economic activity, while $v_{t}$ represented the error random term. However, leading, contemporaneous, and lagging values of REA were incorporated to capture the entire past and leading information on economic activity changes into our estimated models.

In line with Chatrath et al. (1997) and Majid (2006), in Models (3.4) and (3.5), the study included both leads and lags of real economic activity due to lack of prior empirical evidence on the associations 
of real economic activity-inflation-real stock returns in Indonesia by using final prediction error (FPE) criteria. Equations (3.4a), (3.4b), and (3.4c) tested the first Fama's proposition. The negative relationship between inflation and real economic activity indicated that some $\alpha_{i}$ are significantly negative. Equations (3.5a) and (3.5b) were used to test for the second Fama's proposition, in which a positive real economic activity-real stock return relation implied that some $\delta_{l}$ are significantly positive.

Since Fama's proxy hypothesis' explanation was rooted in an indirect real stock returns-inflation connection, a single equation treatment to equations (3.4) and (3.5) could have yielded unreliable estimates (Chatrath et al., 1997; Majid, 2002, 2006). To avoid this inconsistency in the estimates of the association between stock returns and actual, expected, and unexpected inflation, the study employed the procedure of two-step dynamic ordinary least square (DOLS) estimator by using the following equations:

$$
\begin{gathered}
I N F_{t}=\mu_{0}+\sum_{i=-k}^{k} \mu_{i} R E A_{t+i}+\xi_{I t} \\
c S R_{t}-I N F_{t}=\delta_{0}+\delta_{1} \xi_{I t}+\sum_{i=-k}^{k} \gamma_{i} R E A_{t+i}+v_{t} \\
i S R_{t}-I N F_{t}=\delta_{0}+\delta_{1} \xi_{I t}+\sum_{i=-k}^{k} \gamma_{i} R E A_{t+i}+v_{t} \\
E\left(I N F_{t}\right)=\mu_{0}+\sum_{i=-k}^{k} \mu_{i} R E A_{t+i}+\xi_{I I t} \\
c S R_{t}-I N F_{t}=\delta_{0}+\delta_{1} \xi_{I I t}+\sum_{i=-k}^{k} \gamma_{i} R E A_{t+i}+\pi_{t} \\
i S R_{t}-I N F_{t}=\delta_{0}+\delta_{1} \xi_{I I t}+\sum_{i=-k}^{k} \gamma_{i} R E A_{t+i}+\pi_{t} \\
U E\left(I N F_{t}\right)=\mu_{0}+\sum_{i=-k}^{k} \mu_{i} R E A_{t+i}+\xi_{I I I t} \\
c S R_{t}-I N F_{t}=\delta_{0}+\delta_{1} \xi_{I I I t}+\sum_{i=-k}^{k} \gamma_{i} R E A_{t+i}+\phi_{t} \\
i S R_{t}-I N F_{t}=\delta_{0}+\delta_{1} \xi_{I I I t}+\sum_{i=-k}^{k} \gamma_{i} R E A_{t+i}+\phi_{t}
\end{gathered}
$$

In equations (3.6a)-(3.8c), real stock returns and inflation were regressed on the lagging, contemporaneous, and leading values of real economic activity. Nevertheless, the difference between equation (a) and (b) or (c) - for example between equations (3.6a) and (3.6b) or (3.6c) - which was where the estimated residual from equation (3.6a), $\xi_{\text {It }}$ was incorporated as an independent variable in equation (3.6b) or (3.6c), representing the inflation variable that is purged of the inflation-real economic activity relation. For equations (3.6b), (3.7b), and (3.8b), if the estimated $\delta_{1}$ coefficient equalled zero, it would agree with Fama's proxy hypothesis: real stock returns and inflation are independent once we control for the influence of inflation on real economic activity. If the negative relationship between inflation and real stock returns still existed after controlling for the inflation-real economic activity relationship, the results would be inconsistent with Fama's proxy hypothesis.

\section{Data}

Changes in the quarterly consumer price index (CPI) were used to measure inflation, while the growth of gross domestic product (GDP) was used as a proxy for real economic activity (REA). These data were gathered from the Statistical Bulletin of the Central Bureau of Statistics, the Republic of Indonesia. The data for conventional stock return (cSR) and Islamic stock returns (iSR) were calculated from the Jakarta composite index (JCI) and the Jakarta Islamic index (JII), respectively. These stock indices were gathered from the Bloomberg Database (2020). This study utilized non-seasonally adjusted data over the 1999 to 2019 period. All variables investigated in the study were measured using quarterly data.

\section{Expected and unexpected inflation forecasts}

To measure expected and unexpected inflation, this study adopted an auto-regressive integrated moving average (ARIMA) model following the studies by Chatrath et al. (1997) and Majid (2006). This model was suitable due to the instability of the inflation rate like in Indonesia. Besides, the model was also able to detect large variability of inflation rates; therefore, it could have achieved greater predictability of the inflation rate (Mestel \& Gurgul, 2003) and captured the linear patterns of inflation (Pai \& Lin, 2005). 


\section{RESULTS AND DISCUSSION}

\section{Descriptive statistics}

Table 2 reports the descriptive statistics for the investigated variables. As illustrated in Table 2, Islamic stocks offered a slightly higher mean average return $(2.10 \%)$ compared to their conventional counterparts (2.04\%) over the period 2009-2019. Islamic stocks also appeared to be slightly less volatile with a standard deviation of $1.22 \%$ compared to the conventional stock, with a standard deviation of $1.31 \%$. The prohibition of Islamic stocks to involve in riba-, gharar-, and maysir-based activities and speculative transactions are believed to contribute to the higher stability of Islamic stock markets (Majid \& Kassim, 2015).

Table 2. Descriptive statistics

\begin{tabular}{|l|c|c|c|c|}
\hline \multicolumn{1}{|c|}{ Variable } & Minimum & Maximum & Mean & Standard deviation \\
\hline cSR & -0.0268 & 0.0527 & 0.0204 & 0.0131 \\
\hline iSR & -0.0239 & 0.0531 & 0.0210 & 0.0122 \\
\hline INF & 0.0473 & 0.1375 & 0.0617 & 0.0527 \\
\hline E(INF) & 0.0420 & 0.1405 & 0.0634 & 0.0534 \\
\hline UE(INF) & 0.0331 & 0.1501 & 0.0665 & 0.0572 \\
\hline REA (Growth) & 0.0372 & 0.0638 & 0.0506 & 0.0460 \\
\hline
\end{tabular}

Note: $c S R$ is the conventional stock return, iSR is the Islamic stock return, INF is the inflation rate, $E(I N F)$ is the expected inflation rate, UE(INF) is the unexpected inflation rate, and REA is the real economic activity.

Source: own elaboration using the E-Views statistical software.

Furthermore, the inflation rate ranged from $4.73 \%$ to $13.75 \%$ with a mean value of $6.17 \%$ and a standard deviation of $5.27 \%$. The expected inflation rate ranged from $4.20 \%$ to $14.05 \%$ with a mean value of $6.34 \%$ and a standard deviation of 5.34\%. Meanwhile, the unexpected inflation rate ranged from $3.31 \%$ to $15.01 \%$ with a mean value of $6.65 \%$ and a standard deviation of $5.72 \%$. Indonesia recorded the highest rate of inflation in October 2005 due to an increase in the gasoline price by $105 \%$. The lower rate of inflation was mainly caused by the tight monetary policy imposed by the government during the year 2013.

Finally, the growth in real economic activity ranged from $3.72 \%$ to $6.38 \%$ with a mean value of $5.06 \%$ and a standard deviation of $4.60 \%$. The government policy to provide more micro-financing to small and medium enterprises in the year 2010 boosted economic activity to $6.38 \%$. On the other hand, the highest inflation rate caused by an increase in gasoline price had lowered the economic activity to $3.72 \%$ in 2005 .

\section{Test for stationarity}

Table 3 illustrates the findings of the augmented Dickey-Fuller (ADF) test for the presence of unit root test (non-stationarity) for all time-series data using both constant and no trend and with constant and trend regression models. The inflation (INF), expected inflation $[E(I N F)]$, and unexpected inflation [UE(INF)] were found to be stationary in the log level for both models. However, at the log level, the conventional stock ( $c S R$ ) was stationary for the constant and no trend model but was non-stationary with the constant and trend model. Meanwhile, the stock return for Islamic stocks (iSR) and the real

Table 3. Augmented Dickey-Fuller unit-root test

\begin{tabular}{|c|c|c|c|c|}
\hline \multirow{2}{*}{ Variable } & \multicolumn{2}{|c|}{ Log level } & \multicolumn{2}{c|}{ First differences } \\
\cline { 2 - 5 } & Model 1 & Model 2 & Model 1 & Model 2 \\
\hline cSR & $-2.791^{* * *}$ & -2.073 & $-3.863^{* * *}$ & $-4.015^{* * *}$ \\
\hline iSR & -2.102 & -2.132 & $-3.260^{* * *}$ & $-3.432^{* * *}$ \\
\hline INF & $-4.211^{* * *}$ & $-4.163^{* * *}$ & - & - \\
\hline E(INF) & $-4.971^{* * *}$ & $-4.235^{* * *}$ & - & - \\
\hline UE(INF) & $-4.643^{* * *}$ & $-4.176^{* * *}$ & - & - \\
\hline REA & 0.873 & 1.805 & $-3.216^{* * *}$ & $-3.477^{* * *}$ \\
\hline
\end{tabular}

Note: See Table 2. Model 1: constant and no trend, while Model 2: constant and trend. ${ }^{* * *}$ represents significance at the $1 \%$ level. Source: own elaboration using the E-Views statistical software. 
economic activity (REA) were all non-stationary on the log level. Nevertheless, data stationarity was achieved through the first difference for both models.

\section{ARIMA models for expected and unexpected inflation}

As for the ARIMA models, we began with the identification stage, i.e. we identified the exact orders of auto-regressive $(A R)(p)$, integrated $(I)(d)$, and moving average $(\mathrm{MA})(q)$. The unit-root test results (Table 3) showed that the rate of inflation is stationary at the log level; therefore, the order of integration is zero, $\mathrm{I}(0)$. Since the inflation series are stationary, only the auto-regressive moving average (ARMA) $(p, q)$ was implemented. After identifying the $I(0)$, the study determined the orders of both AR and MA.

Table 4. ARMA models for expected inflation

\begin{tabular}{|c|c|}
\hline Parameter & Expected inflation \\
\hline AR (1) & $0.622^{* * *}(4.732)$ \\
\hline AR (2) & $-0.372^{* *}(-2.408)$ \\
\hline AR (3) & $-0.150(-0.933)$ \\
\hline AR (4) & $-0.121(-0.785)$ \\
\hline AR (5) & $-0.251^{* *}(-1.926)$ \\
\hline MA (1) & $0.968^{* * *}(49.110)$ \\
\hline Constant & $0.031^{* * *}(5.007)$ \\
\hline$R^{2}$ & 0.477 \\
\hline Skewness & 0.322 \\
\hline Kurtosis & 3.263 \\
\hline J-B & 2.981 \\
\hline D-W & 2.148 \\
\hline
\end{tabular}

Note: J-B indicates the Jarque-Bera test for normality, whereas D-W refers to the Durbin-Watson $d$ test. The figures in the brackets are t-statistics. ${ }^{* * *}$ and ${ }^{* *}$ indicate significance at $1 \%$ and $5 \%$, respectively.

Source: own elaboration using the E-Views statistical software.

Having identified the appropriate $p, d$, and $q$ values, estimation and forecasting steps were performed, and their findings were reported in Table 4 . Through a diagnostic process, an ARMA $(5,1)^{1}$ was identified to best identify the inflation series, as reported in Table 4 . The goodness of the chosen ARMA model was shown by the insignificances of Modified Box-Pierce chi-square statistics, showing all residuals from the model were white noise and normally distributed. The other criteria for the fitness of a model were indicated by the computed values of skewness and kurtosis, which were 0 and 3 , respectively, for the normal distribution (Gujarati, 2009). The computed values of skewness and kurtosis for the estimated ARMA $(5,1)$ were 0.322 and 3.263 , respectively, indicating the normality of the disturbance term. The Jarque-Bera (J-B) value of 2.981 was found, showing a non-rejection of normality assumption for the estimated model. Finally, as illustrated in Table 4, the estimated Durbin-Watson (DW) value of 2.148 was in the category of non-autocorrelation of the disturbance terms.

\section{Real stock returns and inflation}

Table 5 provides the findings for real stock returns-inflation association, thereby testing the Fisher hypothesis, which states that real stock returns are independent of inflation. For the Islamic stock market, the coefficients of actual inflation (INF), expected inflation E(INF), and unexpected inflation UE(INF) were all insignificant, thereby supporting the Fisher hypothesis. These findings were also supported by the insignificance of the F-statistics and the low coefficient of determination, $R^{2}$ $(0.01 \%-0.13 \%)$, which measured the total variations in real stock returns as explained by the $0.01 \%$ $0.13 \%$ changes in inflation.

\footnotetext{
${ }^{1}$ Box-Pierce chi-square statistics were also computed for $\operatorname{ARMA}(1,5), \operatorname{ARMA}(2,1), \operatorname{ARMA}(2,2), \operatorname{ARMA}(2,3), \operatorname{ARMA}(3,1)$, $\operatorname{ARMA}(3,4)$, ARMA $(4,4)$, ARMA $(5,3)$, and $\operatorname{ARMA}(5,3)$. Even though their skewness and kurtosis values were around 0 and 3 , but the residuals of all these alternative models are non-normally distributed, indicated by the significance of the BoxPierce chi-square statistics.
} 
Our findings supported the earlier empirical findings for the cases of the Malaysian Islamic stock (Haniff \& Masih, 2018), the USA (Gallagher \& Taylor, 2002; Antonakakis et al., 2017), Pakistani (Tiwari et al., 2015), Chinese (Zhao, 2017), Greece (Floros, 2004), and Indian (Jana, 2013) conventional stock markets. The finding of insignificant stock return-inflation relation indicated the better full hedge of Islamic stocks against actual, expected, and unexpected inflation in Indonesia.

As for the conventional stock market, the actual inflation coefficient (Model 1) was negative at the $1 \%$ level of significance, a finding compatible with Fama's hypothesis. As for expected and unexpected inflation, only the unexpected inflation was found to have a negative significance with stock returns at the $1 \%$ level (Model 3). Hence, unlike the findings of the Islamic stock market that supported the Fisher hypothesis, the conventional stock market did not. This finding was similar to empirical evidence found in the stock markets of India (Durai \& Bhaduri, 2009), Malaysia (Majid, 2002), the UK (Li et al., 2010), global economies (Lee, 2010), Canada (Alagidede \& Panagiotidis, 2012), and Turkey (Aktürk, 2016). Our finding of a negative stock return-inflation relationship further indicated that inflation is inseparable from the real side of the economy. The economic consequences of changing inflation on the stock market could not be simply ignored and considered in isolation.

Table 5. Real stock returns-inflation relationship

\begin{tabular}{|c|c|c|c|c|c|c|c|c|}
\hline Stock & Model & Constant & INF & E(INF) & UE(INF) & $\mathbf{R}^{2}$ & $\mathbf{F}$ & D-W \\
\hline \multirow{3}{*}{$c S R-I N F$} & 1 & $\begin{array}{l}-1.125^{* *} \\
(-1.995)\end{array}$ & $\begin{array}{c}-2.774^{* * *} \\
(-2.515)\end{array}$ & - & - & 0.1015 & $5.430^{* * *}$ & 1.954 \\
\hline & 2 & $\begin{array}{l}-1.364^{* *} \\
(-2.116)\end{array}$ & - & $\begin{array}{c}0.283 \\
(0.158) \\
\end{array}$ & - & 0.0005 & $2.245^{* *}$ & 2.144 \\
\hline & 3 & $\begin{array}{l}-1.297^{* *} \\
(-2.284)\end{array}$ & - & $\begin{array}{c}0.378 \\
(0.239) \\
\end{array}$ & $\begin{array}{c}-5.960^{* * *} \\
(-3.963)\end{array}$ & 0.2394 & $7.165^{* * *}$ & 2.242 \\
\hline \multirow{3}{*}{$i S R-I N F$} & 1 & $\begin{array}{c}-1.628 \\
(-1.286)\end{array}$ & $\begin{array}{c}0.870 \\
(0.893)\end{array}$ & - & - & 0.0001 & 1.321 & 2.132 \\
\hline & 2 & $\begin{array}{c}-1.896 \\
(-1.404)\end{array}$ & - & $\begin{array}{c}0.665 \\
(0.744)\end{array}$ & - & 0.0006 & 0.977 & 2.201 \\
\hline & 3 & $\begin{array}{c}-1.704 \\
(-1.377)\end{array}$ & - & $\begin{array}{c}0.397 \\
(0.296)\end{array}$ & $\begin{array}{c}0.199 \\
(0.118)\end{array}$ & 0.0013 & 1.031 & 2.063 \\
\hline
\end{tabular}

Note: CSR - INF and iSR - INF indicate the real value of conventional and Islamic stocks, respectively. Models 1, 2, and 3 for CSR - INF were estimated based on equations (3.1a), (3.2a), and (3.3a). Meanwhile, models 1,2 , and 3 for iSR - INF were estimated based on equations (3.1b), (3.2b), and (3.3b). D-W refers to the Durbin-Watson d test. The numbers in the brackets are the t-statistics. ${ }^{* * *}$ and ${ }^{* *}$ represent a level of significance of $1 \%$ and $5 \%$, respectively.

Source: own elaboration using the E-Views statistical software.

Furthermore, as illustrated in Table 5, the $d$ statistics of the Durbin-Watson (D-W) were all insignificant, indicating a non-autocorrelation among the disturbance terms. Besides, the estimated $\mathrm{R}^{2}$ ranging from $0.05 \%$ (Model 2 ) to $23.94 \%$ (Model 3 ) showed the importance of separating inflation into expected and unexpected inflation. The relatively lower values of estimated $R^{2}$ in our study were consistent with the findings of Lee (2010) and Zhao (2017). They documented rather low $\mathrm{R}^{2}$ in their stock return-inflation models although some other macroeconomic determinants were added into the models.

Furthermore, when comparing the impact of actual, expected, and unexpected inflation on the conventional real stock returns, it was interesting to note that the conventional real stock returns were more dependent on actual and unexpected inflation rather than expected inflation. In contrast, the Islamic real stock returns are independent of actual, expected, and unexpected inflation. These findings show that the Islamic stock market provided a perfect hedge towards inflation, while the conventional stock market did not.

The different nature of Islamic stock resided in its activities being free from the components of interest (riba), gambling (maysir), and uncertainties (gharar), thus causing the Islamic stocks to be less susceptible to changes in macroeconomic variables, including inflation. Thus, the framework of the Islamic capital market limits specific business activities with an emphasis on an ethically-oriented 
transaction, social-oriented investment, sustainable banking and finance and a highly regulated financial system (Yusof \& Majid, 2008; Majid \& Kassim, 2015). Thus, Islam prohibits investing in stocks containing elements of interest ( $r i b a)$, speculation, and excess risk-related business activities, alcohol, ammunition, and pork-related products (Majid, 2016).

Furthermore, Islamic finance rules limit asset-backed stock and equity participation and asset investment, which complies with the sharia injunctions. These characteristics provide a high degree of prudence for Islamic investments, making Islamic finance a promising alternative for improved benefits of investment diversification, particularly in the hyperinflation period. The relatively higher level of inflation in Indonesia (Majid \& Mahrizal, 2007), with an average of $13.75 \%$ over the study period did not affect the values of Islamic stocks. Islamic stocks' ability to grant a full hedge towards inflation offered a promising alternative for improved benefit diversifications among investors while they were investing in halal (permissible) business activities.

Tests for Fama's proxy hypothesis

The first proposition: A negative inflation-real economic activity relation

Table 6 reports the results for the first Proposition of Fama's proxy hypothesis, which tested the presence of a negative relationship between inflation and real economic activity. Earlier, we found that the Islamic stock market provided a good hedge against inflation (Table 5). Thus, the regression results from inflation on real economic activity (Table 6) opposed the first proposition of Fama's proxy effect. Real stock returns were positively related to real economic activity, instead of being negatively related. However, the conventional stock market, which provided some support for the negative relationship between real stock returns and both actual and unexpected inflation (Table 5), did not support the first proposition of Fama's hypothesis.

Table 6. Testing the first proposition of Fama's proxy hypothesis

\begin{tabular}{|c|c|c|c|c|c|c|c|}
\hline \multirow{2}{*}{ Inflation } & \multirow{2}{*}{ Model } & \multicolumn{5}{|c|}{ Real economic activity: Coefficients' sum of lead-lag lengths } \\
\cline { 3 - 8 } & & $\mathbf{( - 3 . 3 )}$ & $\mathbf{( - 5 . 5 )}$ & $\mathbf{( - 7 . 7 )}$ & $\mathbf{( - 9 . 9 )}$ & $\mathbf{( - 1 1 . 1 1 )}$ & FPE \\
\hline \multirow{2}{*}{ INF } & \multirow{2}{*}{1} & $\begin{array}{c}0.0010 \\
{[0.892]}\end{array}$ & -0.0001 & 0.0037 & 0.0008 & -0.0078 & $0.0008^{*}$ \\
& & {$[0.545]$} & {$[1.009]$} & {$[1.129]$} & {$[0.943]$} & {$[2.497](-1.1)$} \\
\hline \multirow{2}{*}{ E(INF) } & \multirow{2}{*}{2} & $0.0012^{* * *}$ & $0.0003^{* * *}$ & & $0.0022^{* * *}$ & $0.0023^{* * *}$ & $0.0018^{* * *}$ \\
& & {$[26.780]$} & {$[25.910]$} & - & {$[18.910]$} & {$[12.884]$} & {$[28.279](-7.7)$} \\
\hline \multirow{2}{*}{ UE(INF) } & \multirow{2}{*}{3} & 0.0002 & -0.0013 & & -0.0003 & $0.0033^{* *}$ & $0.0011^{* * *}$ \\
& & {$[1.391]$} & {$[1.140]$} & - & {$[2.240]$} & {$[3.048]$} & {$[3.343](-7.7)$} \\
\hline
\end{tabular}

Note: models 1, 2, and 3 are estimated based on equations (3.4a), (3.4b), and (3.4c), respectively. The numbers in [.] are the F-statistics, while the numbers in (.) show the optimal lead-lag length based on Akaike's (1969) final prediction error criteria. These numbers include leading, contemporaneous, and lagging values of real economic activity. $* * *, * *$, and $*$ denote significance at the $1 \%, 5 \%$, and $10 \%$ levels, respectively.

Source: own elaboration using the E-Views statistical software.

Table 6 shows that, in the long-time period, there is a positive relationship between actual inflation (Model 1), expected inflation (Model 2), and unexpected inflation (Model 3), and real economic activity. Our study also found that all the estimated FPE based specification models recorded significant F-statistics, thus indicating the models are free from misspecification. It was shown by the positive sum of lead-lag coefficients and significant F-statistics. These findings show that all three types of inflation played a significant positive role in determining real economic activity. This finding contradicts Fama's proxy effect, but it provided some supports to either the Mundell-Tobin hypothesis or the Phillips curve theory.

\section{The second proposition: A positive stock returns-real economic activity relation}

Table 7 provides the findings of the relationship between real stock returns and real economic activity. For the conventional stock market, the FPE based specification Model (-12.12) showed a significant negative real stock returns-real economic activity relationship at the $5 \%$ level. This finding contradicted Fama's proxy hypothesis but provided some supports to the Mundell-Tobin hypothesis. 
Conversely, based on the FPE based specification Models (-1.1), (-3.3), and (-5.5), the Islamic stock market was found to have a positive significant relationship with real economic activity at least at the 5\% level; a finding contradicts the second Fama's proxy proposition. However, the positive inflation-real economic activity and real stock returns-real economic activity showed some consistencies with the Phillips curve theory.

Our estimated FPE-based specification models had the significance of F-statistics, thus indicating the models were free from misspecification. Overall, the findings of a positive inflation-real economic activity and a negative real stock returns-real economic activity relationship for the conventional stock market contradicted Fama's proxy hypothesis but provided some supports to the Mundell-Tobin hypothesis. Our findings agreed with the results of earlier studies by Ram and Spencer (1983) and Chang et al. (2000), who found the explanation of the Mundell-Tobin hypothesis for negative stock return-inflation relationships.

Table 7. Testing the second proposition of Fama's proxy hypothesis

\begin{tabular}{|c|c|c|c|c|c|c|c|}
\hline \multirow{2}{*}{ Stock } & \multirow{2}{*}{ Model } & \multicolumn{6}{|c|}{ Real economic activity: Coefficients' sum of lead-lag lengths } \\
\cline { 3 - 8 } & & $\mathbf{( - 3 . 3 )}$ & $\mathbf{( - 5 . 5 )}$ & $\mathbf{( - 7 . 7 )}$ & $\mathbf{( - 9 . 9 )}$ & $\mathbf{( - 1 1 . ~ 1 1 )}$ & FPE \\
\hline \multirow{2}{*}{ cSR - INF } & \multirow{2}{*}{1} & -0.086 & -0.193 & -0.161 & -0.250 & -0.206 & $-0.234^{* *}$ \\
& & {$[1.168]$} & {$[1.256]$} & {$[0.839]$} & {$[1.671]$} & {$[1.372]$} & {$[2.635](-12.12)$} \\
\hline \multirow{2}{*}{ iSR - INF } & \multirow{2}{*}{2} & $1.979^{* *}$ & $2.167^{* *}$ & 2.084 & -0.694 & -0.505 & $1.193^{* * *}$ \\
& & {$[2.406]$} & {$[2.280]$} & {$[1.418]$} & {$[0.581]$} & {$[0.443]$} & {$[4.601](-1.1)$} \\
\hline
\end{tabular}

Note: see Table 5; models 1 and 2 were estimated based on equations (3.5a) and (3.5b), respectively. Source: own elaboration using the E-Views statistical software.

\section{Real stock returns, inflation, and real economic activity}

Table 8. Real stock returns, actual inflation, and real economic activity

\begin{tabular}{|c|c|c|}
\hline \multirow{2}{*}{$\begin{array}{c}\text { REA: } \\
\text { Lead-lag lengths }\end{array}$} & \multicolumn{2}{|c|}{ Estimated and sum of coefficients } \\
\cline { 2 - 3 } & Conventional stock market & Islamic stock market \\
\hline$(-3.3)$ & $-0.087[1.308]$ & $1.862^{* *}[1.904]$ \\
\hline$(-5.5)$ & $-0.206[1.455]$ & $2.761^{* *}[2.378]$ \\
\hline$(-7.7)$ & $-0.167[0.999]$ & $0.710[0.864]$ \\
\hline$(-9.9)$ & $-0.250^{*}[1.807]$ & $-0.813[0995]$ \\
\hline$(-11.11)$ & $-0.206[1.520]$ & $-0.351[0.578]$ \\
\hline FPE & $-0.228^{* * *}[2.909](-12.12)$ & $1.205^{* * *}[3.404](-1.1)$ \\
\hline$\varepsilon_{\text {It }}$ & $-2.523^{* *}\{-1.745\}$ & $4.877\{0.974\}$ \\
\hline & $\mathrm{R}^{2}=0.788 ;$ Adj- $\mathrm{R}^{2}=0.497 ; \mathrm{D}-\mathrm{W}=1.751 ; \mathrm{J}-\mathrm{B}=2.177$ & $\mathrm{R}^{2}=0.197 ;$ Adj- $\mathrm{R}^{2}=0.189 ; \mathrm{D}-\mathrm{W}=2.058 ; \mathrm{J}-\mathrm{B}=1.989$ \\
\hline
\end{tabular}

Note: these findings were estimated based on equations (3.6a), (3.6b), and (3.6c). ?ilt is the estimated residuals calculated from equation (3.6a), which are then incorporated into equations (3.6b) and (3.6c). This estimate represents the actual inflation variable that is purged of the actual inflation-economic activity relationships for the conventional (equation 3.6b) and Islamic (equation 3.6c) stock markets. The numbers in (.) show the optimal lead-lag length based on the Akaike's (1969) final prediction error criteria, the numbers in [.] are the F-statistics, while the numbers in \{.\} are the t-statistics. J-B and D-W represent the Jarque-Bera test for normality and the Durbin-Watson $d$ test, respectively. ${ }^{* * *}$, ${ }^{* *}$, and ${ }^{*}$ denote the significance levels of $1 \%, 5 \%$, and $10 \%$

Source: own elaboration using the E-Views statistical software.

Even though the finding shows the independence of inflation on real stock returns for Islamic stocks and negative inflation-real stock returns relationship for conventional stocks, so far none of them supports the Fama's proxy hypothesis when both propositions of the Fama's proxy hypothesis are estimated in isolation. Since the framework of Fama's proxy effect is rooted in an indirect stock returns-inflation association, this study further assesses to which extent Fama's proxy effect is consistent and valid to clarify the negative stock returns-inflation relationship for the case of the conventional stock market (Table 5). Tables 8, 9, and 10 report the results from the estimated regression of the real stock returns on purged actual, expected, and unexpected inflation. 
As observed from Table 8, the independence of real stock returns from actual inflation for the Islamic stock market (Model 1 in Table 5) still existed even after controlling for the effect of real economic activity on actual inflation. This is confirmed by the insignificance of $\varepsilon_{\mid t}$ (Table 8). Since Fama's proxy hypothesis expounds the negative stock returns-inflation nexus; therefore, this hypothesis cannot be used to describe the independence between variables observed for the Islamic stock market.

In the case of the conventional stock market, the results are documented to be inconsistent with Fama's proxy hypothesis where a negative relationship between real stock returns and actual inflation (Model 1 in Table 5) remained persistently significant (Table 8) even after controlling for the inflationreal economic activity relationship; the findings similar to Wahlross and Berglund (1986). The negative relationship between real stock returns and actual inflation is evidenced by the negative significance of $\varepsilon_{\mid t}$ at the $5 \%$ level. In general, the results from Table 5 (Model 1 ) and Table 8 were not much different. Actual inflation affected negatively real stock returns, although at a lesser level of significance.

Table 9 further reports the results from the estimated regression of the real stock returns on purged expected inflation. For the case of the Islamic stock market, the independence of real stock returns from inflation still existed even after controlling for the effect of real economic activity on inflation, represented by the insignificance of $\varepsilon_{\| t t}$. These findings are compatible with the evidence from Table 5 (Model 2). These findings showed that Fama's proxy hypothesis that delineates the negative stock returns-inflation nexus is unable to describe the independence of Islamic stock returns from expected inflation. Similarly, for the case of the conventional stock market, the independence of real stock returns from expected inflation persisted even after controlling for the influence of real economic activity on expected inflation. This was evidenced by the insignificance of $\varepsilon_{\text {lit }}$ (Table 9). These findings further confirmed the inability of Fama's proxy hypothesis to explain the nature of stock returns-inflation nexus for the case of Indonesian stock markets.

Table 9. Real stock returns, expected inflation, and real economic activity

\begin{tabular}{|c|c|c|}
\hline \multirow{2}{*}{$\begin{array}{c}\text { REA: } \\
\text { Lead-lag lengths }\end{array}$} & \multicolumn{2}{|c|}{ Estimated and sum of coefficients } \\
\cline { 2 - 3 } & Conventional stock market & Islamic stock market \\
\hline$(-3.3)$ & $-0.107[1.178]$ & $0.349[0.769]$ \\
\hline$(-5.5)$ & $-0.206[1.029]$ & $-0.201[0.572]$ \\
\hline$(-7.7)$ & $-0.052[0.827]$ & $0.718[1.119]$ \\
\hline$(-9.9)$ & $-0.196[1.544$ & $-0.048[0.491]$ \\
\hline$(-11.11)$ & $-0.573^{* * *}[3.301]$ & $0.307[0.682]$ \\
\hline FPE & $-0.461^{* * *}[4.547](-12.12)$ & $1.273^{* *}[2.163](-1.1)$ \\
\hline$\varepsilon_{\text {IIt }}$ & $3.618\{0.827\}$ & $-4.052\{-0.915\}$ \\
\hline & $\mathrm{R}^{2}=0.889 ; \mathrm{Adj}-\mathrm{R}^{2}=0.682 ; \mathrm{D}-\mathrm{W}=1.485 ; \mathrm{J}-\mathrm{B}=3.283$ & $\mathrm{R}^{2}=0.204 ; \mathrm{Ad}-\mathrm{R}^{2}=0.197 ; \mathrm{D}-\mathrm{W}=1.708 ; \mathrm{J}-\mathrm{B}=2.640$ \\
\hline
\end{tabular}

Note: these findings were estimated based on equations (3.7a), (3.7b), and (3.7c). $\varepsilon_{|| t}$ was the estimated residuals calculated from equation (3.7a), which are then incorporated into equations (3.7b) and (3.7c). This estimate represents the expected inflation variable that is purged of the expected inflation-economic activity relationships for the conventional (equation $3.7 \mathrm{~b}$ ) and Islamic (equation 3.7c) stock markets. The numbers in (.) show the optimal lead-lag length based on the Akaike's (1969) final prediction error criteria, the numbers in [.] are the F-statistics, while the numbers in \{.\} are the t-statistics. Source: own elaboration using the E-Views statistical software.

Finally, Table 10 reports the finding from the estimated regression of the real stock returns on purged unexpected inflation. The study found that the independence of real stock returns from unexpected inflation for the Islamic stock market (Model 3 in Table 5) still existed even after controlling for the effect of real economic activity on expected inflation. This was evidenced by the insignificance of $\varepsilon_{\text {IIIt }}$ (Table 10). Thus, Fama's proxy hypothesis that explains a negative stock returns-inflation nexus cannot be used to describe the independence of Islamic stock returns from unexpected inflation.

On the contrary, the findings for the conventional stock market were recorded to be inconsistent with Fama's proxy hypothesis, in which the negative real stock returns-unexpected inflation relationship (model 3 in Table 5) remained persistently significant (Table 10), even after controlling for the unexpected inflation-real economic activity relationship. This was confirmed by the negative significance of $\varepsilon_{\text {IIIt }}$ at the $10 \%$ level. In general, the results from Table 5 (model 3 ) agreed with the findings in 
Table 10. Unexpected inflation influenced negatively real stock returns, although at a lesser level of significance. Our findings agreed with Wahlross and Berglund (1986).

Overall, our results showed that Fama's proxy effect framework cannot fully explain the independence of real stock returns on inflation for the Islamic stock market. Moreover, Fama's proxy hypothesis failed to clarify the strong negative real stock returns-inflation relationship for the conventional stock market. Instead, our findings offered some support to the Mundell-Tobin hypothesis. Our findings are similar to earlier studies by Ram and Spencer (1983) and Chang et al. (2000), who record that a negative real stock returns-inflation relationship is directly explained by the positive inflation-real activity and the negative real stock returns-real activity relationships.

Table 10. Real stock returns, unexpected inflation, and real economic activity

\begin{tabular}{|c|c|c|}
\hline \multirow{2}{*}{$\begin{array}{c}\text { REA: } \\
\text { Lead-lag lengths }\end{array}$} & \multicolumn{2}{|c|}{ Estimated and sum of coefficients } \\
\cline { 2 - 3 } & Conventional stock market & Islamic stock market \\
\hline$(-3.3)$ & $-0.085^{* * *}[2.370]$ & $0.339[0.740]$ \\
\hline$(-5.5)$ & $-0.193^{* *}[2.186]$ & $-0.372[0.855]$ \\
\hline$(-7.7)$ & $-0.150[1.520]$ & $0.909[0.529]$ \\
\hline$(-9.9)$ & $-0.247^{* *}[1.902]$ & $0.249[0.527]$ \\
\hline$(-11.11)$ & $-0.227[1.500]$ & $-0.770[0.409]$ \\
\hline FPE & $-0.245^{* *}[2.807](-12.12)$ & $1.204^{* * *}[2.977](-1.1)$ \\
\hline$\varepsilon_{\text {IIIt }}$ & $-2.342^{*}\{-1.556\}$ & $3.758\{1.003\}$ \\
\hline & $\mathrm{R}^{2}=0.894 ;$ Adj-R ${ }^{2}=0.697 ; \mathrm{D}-\mathrm{W}=1.644 ; \mathrm{J}-\mathrm{B}=3.815$ & $\mathrm{R}^{2}=0.210 ;$ Adj-R $\mathrm{R}^{2}=0.207 ; \mathrm{D}-\mathrm{W}=1.704 ; \mathrm{J}-\mathrm{B}=2.704$ \\
\hline
\end{tabular}

Note: these findings are estimated based on equations (3.8a), (3.8b), and (3.8c). $\varepsilon_{\text {IIIt }}$ was the estimated residuals calculated from equation (3.8a), which are then incorporated into equations (3.8b) and (3.8c). This estimate represents the unexpected inflation variable that is purged of the unexpected inflation-economic activity relationships for the conventional (equation 3.8b) and Islamic (equation 3.8c) stock markets. The numbers in (.) show the optimal lead-lag length based on the Akaike's (1969) final prediction error criteria, the numbers in [.] are the F-statistics, while the numbers in \{.\} are the t-statistics. Source: own elaboration using the E-Views statistical software.

\section{CONCLUSIONS}

This study empirically explored the effects of actual, expected, and unexpected inflation on conventional and Islamic stock markets over the 1999-2019 period in Indonesia. The study documented that real returns of Islamic stocks are independent of inflation, implying a perfect hedge of the Islamic stocks against inflation, as suggested by the Fisher hypothesis. However, for the conventional stock market, the study documented a negative relationship between real stock returns and both actual and unexpected inflation, implying an inability of conventional stocks to provide a good hedge against inflation.

To further explain the negative relationship between stock returns and inflation, the study examined both propositions of Fama's proxy effect framework, which centres on a negative inflation-economic activity and a positive stock returns-economic activity relationship. For the Islamic stock case, the positive relationships are found both between real economic activity-inflation and economic activity-real stock returns. These findings contradicted Fama's proxy effect but supported the Phillips curve theory. As for the conventional stock case, Fama's proxy effect failed to explain the negative real stock returns-inflation relationship. The study revealed the positive inflation-economic activity and the negative stock returnseconomic activity relationships. However, our results support the Mundell-Tobin hypothesis, in which the negative real stock returns-inflation relationship is directly explained by the positive inflation-economic activity and the negative stock returns-economic activity associations.

The reliability of Fama's proxy hypothesis is then subsequently confirmed by establishing a twostep estimation that controls for the inflation-economic activity relationship. The study still found the independence of real stock returns on inflation for the Islamic stock market, consistently against Fama's proxy hypothesis. The negative real stock returns-inflation relationship for the conventional stock market still existed even though at a lesser level of significance.

This study only focused its analysis on the relationships between inflation and returns of Indonesia's conventional and Islamic stocks within the framework of Fama's proxy hypothesis. Future studies should 
consider the adoption of alternatives models, such as GARCH and VAR to predict expected and unexpected inflation. Further studies on this issue might also consider the dynamic causal relationship between inflation-stock returns and incorporate relevant control variables to provide more reliable empirical evidence on the nature of inflation-stock return nexus. Testing the nature of the inflation-stock return nexus using various hypotheses and theories would enrich the existing empirical findings. Finally, incorporating more Islamic and conventional stocks from the Asian emerging market, advanced European, and the US stock markets into the analysis, future studies would offer more comprehensive findings.

\section{REFERENCES}

Akaike, H. (1979). A Bayesian extension of the minimum AIC procedure of autoregressive model fitting. Biometrika, 66(2), 237-242. https://doi.org/10.1093/biomet/66.2.237

Aktürk, H. (2016). Do stock returns provide a good hedge against inflation? An empirical assessment using Turkish data during periods of structural change. International Review of Economics \& Finance, 45, 230-246. https://doi.org/10.1016/j.iref.2016.06.002

Alagidede, P., \& Panagiotidis, T. (2012). Stock returns and inflation: Evidence from quantile regressions. Economics Letters, 117(1), 283-286. https://doi.org/10.1016/ j.econlet.2012.04.043

Antonakakis, N., Gupta, R., \& Tiwari, A.K. (2017). Has the correlation of inflation and stock prices changed in the United States over the last two centuries?. Research in International Business and Finance, 42, 1-8. https://doi.org/10.1016/j.ribaf.2017.04.005

Bloomberg Database. (2020). Daily Stock Price Indices. Asia Pacific: Bloomberg database.

Brandt, M.W., \& Wang, K.Q. (2003). Time-varying risk aversion and unexpected inflation. Journal of Monetary Economics, 50(7), 1457-1498. https://doi.org/10.1016/ j.jmoneco.2003.08.001

Bulmash, S.B. (1991). Stock prices, inflation, and money supply: A re-examination. In S-N. Chen \& C-F. Lee (Eds.), Advances in investments analysis and portfolio management. London, England: JAI Press.

Central Bureau of Statistics of the Republic of Indonesia. (1999-2020). Quarterly Statistical Bulletin. Jakarta: Badan Pusat Statistik.

Chang, W.Y., Hsieh, Y.N., \& Lai, C.C. (2000). Social status, inflation, and endogenous growth in a cash-in-advance economy. European Journal of Political Economy, 16(3), 535-545. https://doi.org/10.1016/S01762680(00)00011-2

Chatrath, A., Ramchander, S., \& Song, F. (1997). Stock prices, inflation and output: evidence from India. Applied Financial Economics, 7(4), 439-445. https://doi.org/10.1080/096031097333556

Durai, S.R.S., \& Bhaduri, S.N. (2009). Stock prices, inflation and output: Evidence from wavelet analysis. Economic Modelling, 26(5), 1089-1092. https://doi.org/10.1016/j.econmod.2009.04. 005

Fama, E.F. (1981). Stock returns, real activity, inflation, and money. The American Economic Review, 71(4), 545-565.

Fama, E.F. (1983). Stock returns, real activity, inflation, and money: Reply. American Economic Review, 73(3), 471-472.

Feldstein, M. (1982). Inflation and the stock market: reply. The American Economic Review, 72(1), 243-246.

Fisher, I. (1930). The Theory of Interest. New York: Macmillan.

Floros, C. (2004). Stock returns and inflation in Greece. Applied Econometrics and International Development, $4(2), 55-68$.

Gallagher, L.A., \& Taylor, M.P. (2002). The stock return-inflation puzzle revisited. Economics Letters, 75(2), 147156. https://doi.org/10.1016/S0165-1765(01)00613-9

Gujarati, D.N. (2009). Basic econometrics. New York: McGraw-Hill.

Haniff, N.M., \& Masih, A.M.M. (2018). Do Islamic stock returns hedge against inflation? A wavelet approach. Emerging Markets Finance and Trade, 54(10), 2348-2366. https://doi:10.1080/1540496x.2017.1363035

Hess, P.J., \& Lee, B.S. (1999). Stock returns and inflation with supply and demand disturbances. The Review of Financial Studies, 12(5), 1203-1218. https://doi.org/10. 1093/rfs/12.5.1203

Jana, S. (2013). Applicability of Fisher hypothesis on pre \& post reforms era of Indian capital market. International Journal Management, 2(2), 1-11. 
Kaul, G. (1987). Stock returns and inflation: The role of the monetary sector. Journal of Financial Economics, 18(2), 253-276. https://doi.org/10.1016/0304-405X(87)90041-9

Kaul, G. (1990). Monetary regimes and the relation between stock returns and inflationary expectations. Journal of Financial and Quantitative Analysis, 25(3), 307-321. https://doi.org/10. 2307/2330698

Kim, J.R. (2003). The stock return-inflation puzzle and the asymmetric causality in stock returns, inflation and real activity. Economics Letters, 80(2), 155-160. https://doi.org/10.1016/S0165-1765(03)00059-4

Kryzanowski, L., \& Rahman, A.H. (2009). Generalized Fama proxy hypothesis: Impact of shocks on Phillips curve and relation of stock returns with inflation. Economics Letters, 103(3), 135-137. https://doi.org/10.1016/j.econlet.2009.03.001

Lee, B.S. (2010). Stock returns and inflation revisited: An evaluation of the inflation illusion hypothesis. Journal of Banking \& Finance, 34(6), 1257-1273. https://doi.org/10.1016/j.jbankfin. 2009.11.023

Li, L., Narayan, P.K., \& Zheng, X. (2010). An analysis of inflation and stock returns for the UK. Journal of International Financial Markets, Institutions and Money, 20(5), 519-532. https://doi.org/10.1016/j.intfin.2010.07.002

Majid, M.S.A. (2006). Does the Indonesian stock market provide a good hedge against inflation? Evidence from the pre-1997 financial turmoil. Journal of Economic Cooperation, 27(2), 71-100.

Majid, M.S.A. (2016). Dynamic interactions between the Islamic stock prices and macroeconomic variables: evidence from Malaysia. DLSU Business \& Economics Review, 26(1), 92-100.

Majid, M.S.A., \& Mahrizal. (2007). Does financial development cause economic growth in the ASEAN-4 countries? Savings and Development, 16(4), 369-398.

Majid, M.S.A., \& Kassim, S.H. (2015). Assessing the contribution of Islamic finance to economic growth: Empirical evidence from Malaysia. Journal of Islamic Accounting and Business Research, 6(2), 292-310. https://doi.org/10.1108/JIABR-07-2012-0050

Mestel, R., \& Gurgul, H. (2003). ARIMA modeling of event induced stock price reactions in Austria. Central European Journal of Operations Research, 11(4), 317-333.

Modigliani, F., \& Cohn, R.A. (1979). Inflation, rational valuation and the market. Financial Analysts Journal, 35(2), 24-44.

Modigliani, F., \& Cohn, R.A. (1982). Inflation, rational valuation, and the market. In G-P. Szego \& M. Sarnat (Eds.), Saving, investment, and capital markets in an inflationary economy. The USA: Ballinger Publishing Company.

Mundell, R. (1963). Inflation and real interest. Journal of Political Economy, 71(3), 280-283.

Pai, P.F., \& Lin, C.S. (2005). A hybrid ARIMA and support vector machines model in stock price forecasting. Omega, 33(6), 497-505. https://doi.org/10.1016/j.omega. 2004.07.024

Phillips, A.W. (1958). The relation between unemployment and the rate of change of money wage rates in the United Kingdom, 1861-1957. Economica, 25(100), 283-299.

Qizam, I. (2020). Do sukuk ratings non-contingently affect stock returns? Evidence from Indonesia and Malaysia. Entrepreneurial Business and Economics Review, 9(1), 137-153. https://doi.org/10.15678/EBER.2021.090109

Ram, R., \& Spencer, D.E. (1983). Stock returns, real activity, inflation, and money: comment. The American Economic Review, 73(3), 463-470.

Tiwari, A.K., Dar, A.B., Bhanja, N., Arouri, M., \& Teulon, F. (2015). Stock returns and inflation in Pakistan. Economic Modelling, 47, 23-31. https://doi.org/10.1016/j.econmod. 2014.12.043

Tobin, J. (1965). Money and economic growth. Econometrica: Journal of the Econometric Society, 671-684.

Wahlroos, B., \& Berglund, T. (1986). Stock returns, inflationary expectations and real activity: New evidence. Journal of Banking \& Finance, 10(3), 377-389. https://doi.org/10.1016/S0378-4266(86)80027-9

Yusof, R.M., \& Majid, M.S.A. (2008). Towards an Islamic international financial hub: The role of Islamic capital market in Malaysia. International Journal of Islamic and Middle Eastern Finance and Management, 1(4), 313329. https://doi.org/10.1108/17538390810919628

Zhao, L. (2017). Stock returns under hyperinflation: Evidence from China 1945-48. China Economic Review, 45, 155-167. https://doi.org/10 


\section{Authors}

The first author contributed $55 \%$ to the manuscript (introduction, literature review, findings, and discussion), the second author contributed $25 \%$ to the manuscript (research methods, processed statistical analysis, and conclusions), while the remaining $20 \%$ was contributed by the third author (enriching discussion and implications of the study).

\section{Yahya}

Associate Professor at the Department of Management, Sekolah Tinggi Ilmu Ekonomi Sabang (STIES), Banda Aceh, Indonesia. Ph.D. in Economics (2016); Master's in Economics (1997); and Bachelor of Economics (1986) from Universitas Syiah Kuala (USK), Indonesia. His research interests include macroeconomics, regional economics, and economic development.

Correspondence to: Dr. Yahya, S.E., M.Si, Department of Management, Sekolah Tinggi Ilmu Ekonomi Sabang (STIES), Banda Aceh, Indonesia, e-mail: yahya_kobat@rocketmail.com

ORCID (1) http://orcid.org/0000-0002-9056-3880

\section{Shabri Abd. Majid}

Professor of Islamic Economics at the Faculty of Economics and Business, Universitas Syiah Kuala (USK), Indonesia. Ph.D. in Financial Economics (2005); Master's in Economics (1998) from International Islamic University Malaysia; and Bachelor of Management Sciences (1995) from USK, Indonesia. His research interests include financial economics, Islamic economics, banking, and finance. He has published more than 60 articles in the Scopus Indexed Journals.

Correspondence to: Prof. Dr. M. Shabri Abd. Majid, Faculty of Economics and Business, Universitas Syiah Kuala (USK), Darussalam, Banda Aceh, 23111, Indonesia, e-mail: mshabri@unsyiah.ac.id

ORCID 가 http://orcid.org/0000-0003-3558-8783

\section{Hafasnuddin}

Associate Professor at the Department of Management, Faculty of Economics and Business, Universitas Syiah Kuala (USK), Indonesia. Ph.D. in Islamic Banking Marketing (2008) from Universitas Padjajaran, Indonesia; Master's in Marketing (1994) from the University of Illinois, USA; and Bachelor of Management Sciences (1986) from USK, Indonesia. His research interests include Islamic banking marketing, Islamic management, and Islamic economics, banking, and finance. He has published many articles in the reputable international journals. Correspondence to: Dr. Hafasnuddin, SE., MBA, Faculty of Economics and Business, Universitas Syiah Kuala (USK), Darussalam, Banda Aceh, 23111, Indonesia, e-mail: hafas50@yahoo.com ORCID (1) http://orcid.org/0000-0003-0350-8451

\section{Acknowledgements and Financial Disclosure}

The authors would like to thank the anonymous referees for their useful comments, which allowed them to improve the quality of this article.

\section{Conflict of Interest}

The authors declare that the research was conducted in the absence of any commercial or financial relationships that could be construed as a potential conflict of interest.

\section{Copyright and License}

This article is published under the terms of the Creative Commons

Attribution - NoDerivs (CC BY-ND 4.0) License

http://creativecommons.org/licenses/by-nd/4.0/ 